\title{
SITUATIONS WHICH PRECIPITATE CONFLICTS IN THE CONJUGAL RELATIONSHIP: THE WOMEN'S DISCOURSE
}

\author{
Gilvânia Patrícia do Nascimento Paixão ${ }^{1}$, Nadirlene Pereira Gomes², Normélia Maria Freire Diniz ${ }^{3}$, Telmara \\ Menezes Couto ${ }^{4}$, Lucila Amaral Carneiro Vianna ${ }^{5}$, Sheila Milena Pessoa dos Santos ${ }^{6}$
}

\footnotetext{
${ }^{1}$ M.Sc. in Nursing. Assistant professor at the Univesidade do Estado da Bahia. Senhor do Bonfim, Bahia, Brazil. E-mail: gilvania. paixao@gmail.com

${ }^{2}$ Ph.D. in Nursing. Adjunct professor of the Universidade Federal da of Bahia (UFBA). Salvador, Bahia, Brazil. Email: nadirlenegomes@hotmail.com

${ }^{3}$ Ph.D. in Nursing. Adjunct professor of the UFBA. Salvador, Bahia, Brazil. E-mail: normeliadiniz@gmail.com

${ }^{4}$ Ph.D. in Nursing. Adjunct professor of the UFBA. Salvador, Bahia, Brazil. E-mail: telmaracouto@gmail.com

${ }^{5}$ Ph.D. in Public Health. Adjunct professor of the Universidade Federal de São Paulo. São Paulo, State of São Paulo, Brazil. E-mail: lvianna@unifesp.br

${ }^{6}$ M.Sc. in Education. Assistant professor of the Universidade Federal de Campina Grande. Campina Grande, Paraíba, Brazil. E-mail: sheila.milena@gmail.com
}

\begin{abstract}
This study aimed to analyze the situations that precipitate and/or intensify conflicts in the conjugal relationship. Interviews were held with 19 women experiencing conjugal violence. The Discourse of the Collective Subject was used as the method of organization, making it possible to find the central ideas, and gender was used as the analytical framework. Summary: the women report the man's control and domination of the woman, jealousy, the male partner's infidelity, unplanned fatherhood and motherhood, and the use of alcohol and drugs. These situations are related to the construction of the conjugal violence and/or the woman's remaining in the relationship, with preventive actions being essential so as to avoid this phenomenon and its repercussions on the health of the woman and the family. The work of the professional nurse is indispensable in the programs for harm prevention and for the promotion and assistance of the health of women and families, through social and health service means and facilities existing in the community. DESCRIPTORS: Violence against women. Family relationships. Family conflict. Gender violence. Nursing.
\end{abstract}

\section{SITUAÇÕES QUE PRECIPITAM CONFLITOS NA RELAÇÃO CONJUGAL: O DISCURSO DE MULHERES}

RESUMO: A pesquisa objetivou analisar as situações que precipitam e/ou intensificam conflitos na relação conjugal. Foram entrevistadas 19 mulheres em vivência de violência conjugal. Utilizou-se o Discurso do Sujeito Coletivo como método de organização, que possibilitou encontrar as ideias centrais e gênero como referencial analítico. Síntese: relação de controle e dominação do homem para com a mulher, os ciúmes, a infidelidade do companheiro, a paternidade e maternidade sem planejamento e o uso de álcool e drogas. Tais situações guardam relação com a construção da violência conjugal e/ou permanência da mulher na relação, sendo essenciais as ações de prevenção, a fim de evitar tal fenômeno, bem como suas repercussões para a saúde da mulher e da família. A atuação do profissional enfermeiro é indispensável nos programas de prevenção de agravos, promoção e assistência à saúde das mulheres e famílias, por meio dos equipamentos de saúde e sociais existentes na comunidade.

DESCRITORES: Violência contra a mulher. Relações familiares. Conflito familiar. Violência de gênero. Enfermagem.

\section{SITUACIONES QUE CAUSAN CONFLICTOS EN LA RELACIÓN CONYUGAL: EL DISCURSO DE LAS MUJERES}

\begin{abstract}
RESUMEN: La investigación tiene como objetivo el análisis de las situaciones que precipitan y/o intensifican los conflictos en la relación conyugal. Fueran entrevistadas 19 mujeres que viven la violencia conyugal. Se utilizó el Discurso de Sujeto Colectivo, que posibilitó encontrar las ideas centrales y el género como un marco analítico. Síntesis: relación de control y dominación del hombre para con la mujer, celos, la infidelidad de la pareja, la paternidad y maternidad sin plan y el uso de alcohol y drogas. Estas situaciones tienen relación con la construcción de la violencia conyugal y / o la permanencia de la mujer en la relación, así, son esenciales acciones de prevención para evitar tal fenómeno y las consecuencias para la salud de la mujer y de la familia. La función del profesional enfermero es indispensable en los programas de prevención de agravios, promoción y de asistencia a la salud de las mujeres y familias, a través de los equipos de salud existentes en la comunidad.
\end{abstract}

DESCRIPTORES: Violencia contra la mujer. Relaciones familiares. Conflicto familiar. Violencia de género. Enfermería. 


\section{INTRODUCTION}

Interpersonal relationships are subject to conflicts. The central question, however, is how these disagreements are resolved, as they may precipitate or intensify disrespectful and violent actions, with repercussions for the health of the woman and the entire family, principally the children.

It is important to state that conflict per se is not harmful, as diversity necessarily creates conflicts, these being inevitable and essential for the improvement of the relationships between people. ${ }^{1}$ The conflicts can be positive or negative, depending on how we face and resolve them. ${ }^{2}$

Dialogue is the most peaceful way of solving problems, as it allows both parties to reach an agreement. A study on the peace promotion networks, undertaken in São Paulo, in the State of São Paulo (SP), Brazil, emphasizes the importance of dialogue for coping with conflicts and condemns the use of violence. ${ }^{1}$ In this regard, violence represents a non-peaceful way of responding to a specified situation, harming and negating the other person. ${ }^{2}$

In daily life, conjugal violence possesses a vicious circle with three different stages, beginning in a period of conflicts, which leads to tension between the couple; followed by the phase of the violence itself, in which the aggressor loses emotional and physical control; followed by the phase of reconciliation, when the aggressor shows repentance and attempts to compensate for their violent behavior, with attitudes of tenderness and conciliation. $^{3}$

It is very common for this cycle to repeat with increasing violence and diminishing intervals between the phases, triggering problems for the woman's health of varying dimensions and complexities, ranging from physical injuries such as hematomas, to those related to psycho-emotional aspects, such as depression or suicides. ${ }^{4}$ In this regard, the professionals who work in primary health care have a privileged locus, as they are very close to the community, which favors the identification of health issues such as the experiencing of violence. Nurses, being members of the specialist teams in the health centers and, usually, managing these teams, must include active listening and being alert in their routine, so as to seek to prevent the problem, based on the routine elements of their work, whether the nursing history or the physical examinations, or even the procedures undertaken in the assistance, allowing early identification of this health issue. ${ }^{5}$

In addition, constant rows between women and their partners have important repercussions in the lives of their children, such as psychological disturbances, as the family functions as a complex system in which the members are interdependent on each other, and the spouses are the fundamental structure, such that any imbalance in the conjugal relationship influences the balance of the family. ${ }^{6-7}$ The repercussions of conjugal violence for the entire family reveal the magnitude of the phenomena. ${ }^{8}$

A study undertaken with families in Brasília, in the Federal District of Brazil, argues that for a good family relationship, communication is essential in the process of coping with conjugal conflicts. However, this study revealed that in conflictual situations, only $35 \%$ of the women, and $30 \%$ of the men, seek dialogue as a means of solving the problem. ${ }^{7}$ It is clear, therefore, that conjugal violence is constructed on a foundation of poorly-resolved conflicts, which are normally simple reasons, even banal ones, but which with time are accentuated, resulting in conjugal violence. ${ }^{2,4}$ In the light of this context, we ask the question: which day-today situations contribute to precipitating and/or intensifying conjugal violence?

Reinforcing the importance of studies on this issue, the Maria da Penha Law* recommends the promotion of studies in the viewpoint of gender seeking to identify the causes of domestic and family violence against women. ${ }^{9}$ To this one can add the fact that the 1988 Brazilian Federal Constitution, in paragraph 8 , article 226 , indicates the need for creating mechanisms for curbing violence in the ambit of family relationships. ${ }^{10}$

Considering the above, this study's objective was to analyze the situations which precipitate/intensify conflicts in the conjugal relationship, based on the women's discourse.

\section{METHODS}

This is descriptive qualitative research. The qualitative study is shown to be appropriate for the object proposed, above all for entering the universe of the families, as it considers that the experience of conjugal violence has individual,

\footnotetext{
* The Maria da Pena Law (Federal Law N. 11340) aims to reduce domestic violence through a variety of measures. Translator's note.
} 
family and collective repercussions and that it is important to understand this phenomenon in order to promote strategies for confronting it. As it is a method which assists in penetrating the complexity of the human being, the qualitative approaches have offered opportunities for the health professionals to understand the meanings, beliefs and values which guide human behavior. ${ }^{11}$ This study analyzed the situations which precipitate/ intensify conflicts in the conjugal relationship.

This study is linked to the action-research titled "Confronting conjugal violence: strategies for ensuring the families' safety and health", financed by the Bahia State Research Support Foundation (FAPESB). ${ }^{12}$ The study was undertaken in a neighborhood of the city of Salvador, in the state of Bahia, Brazil. An association exists in this neighborhood providing support for the community, providing spaces for entertainment, education and health. Set up in 1992, this association proposes to discuss issues linked to domestic violence. This institution was the nurse-researchers' link with the community, even helping with the selection of possible collaborators. So as to guarantee its privacy, in the study, it will be referred to simply as "the association".

The participants were 19 women living in the above-mentioned community, who met the following inclusion criteria: to be over 18 years old, to be in a conjugal situation, and to have a history of conjugal violence. After the women who met these inclusion criteria were identified, they were invited to participate in the interview, which was held in a room belonging to the association.

This research followed basic benchmarks of autonomy, non-maleficence, beneficence and justice and other ethical aspects set out in Resolution 196/96 of the National Health Council, which regulates practices involving research involving human beings. ${ }^{13}$ It was approved by the Research Ethics Committee (REC) of the Federal University of Bahia's (UFBA) School of Nursing, under Opinion N. 42/2011.

Data collection was initiated following the REC's approval, using interviews with a semistructured questionnaire allowing the interviewer to insert questions which arose and were relevant during collection. ${ }^{14}$ The interview was guided by the initial guidance: "Tell me about the reasons which lead you and your partner argue/fight". Data collection took place between March and May 2012.

The Discourse of the Collective Subject (DCS) was used for organizing the data. In this method, the collective thinking is linked not to the sum of the individual thoughts (a numerical percentage representation) but, rather, to the social imaginary, to the social representations, to the pre-existing thought. The proposal of the DCS aims, above all else, to identify the due correlations which the collectivity brings in its discourse and which carry the intrinsic values, belonging to that culture, which are present in the routine of the social subjects. ${ }^{15-16}$

Following the method's assumptions, some stages must be undertaken, as stated below: 1) Transcribe in full the accounts resulting from the interview; 2) Analyze the verbal material collected, extracting the following methodological features from each one of the oral statements: Central Ideas (CI) and their respective Key Expressions (KE); and 3) Make up the various summary-discourses, termed the Discourse of the Collective Subject, based on the $\mathrm{CI}$ and the KE. ${ }^{16}$

The CI is understood as a name or expression which translates the essence of the discursive content presented by the subjects in their statements. It is, therefore, a synthetic and accurate way of describing or revealing the meaning and the theme of the Key Expressions of each one of the oral statements. ${ }^{15}$ Briefly, the CI states what the subject talks about. The KE, on the other hand, is what the subject actually said. It is also noteworthy that a single discourse can reveal various $\mathrm{CI}$ and KE. Thus, following these precepts, following the transcription of the account, the convergent ideas were extracted and the collective discourses were made up, which were analyzed within the analytical framework of gender.

\section{RESULTS}

The majority of the women interviewed are characterized as young, black, with a low educational level, economically dependent on their parents or partners, and living with children in a stable relationship with the partner. It is worth emphasizing the presence of the use of licit and illicit drugs by the interviewees and also by their spouses.

The study revealed that the relationship of control and domination by the man of the woman, jealousy, the partner's infidelity, unplanned father- and motherhood and the use of alcohol and drugs are situations which precipitate and/ or intensify conflicts in the conjugal relationship, according to the women's discourse. These findings are shown through the summary central ideas presented below. 


\section{Summary central idea A: the relationship of control and domination by the man of the woman.}

In this summary central idea, it is possible to perceive the relationship of control and domination which the man establishes over the woman in the conjugal relationship, this relationship being permeated by issues of gender, and culminating in conjugal violence.

I think the worst thing is the machismo. Like, the man thinks he is our owner. He really does like ordering me around and sometimes wants to give me orders. He wants to deprive me of some things, it is horrible. He wants the world to revolve around him. If I disagree about something he wants, there is an argument. He thinks he doesn't have any responsibility for his son, that that is all my business. He wants me to stay inside the house. He himself said that he gets irritated because I chat to people on the street, talking with other people, and he says that a respectable woman doesn't hang dilly-dally on the street. He has a very sexist mindset. He stays waiting for me at the door at work. If I am late, he says that I was supposed to be there at such and such time, which was ' $x$ ' minutes ago, "I would prefer you not to work, that you stayed at home". Also, there is the issue of sex, he wants sex every day and I don't, but often I would say that I didn't want to, and that argument would start, and in the end we would always end up doing it because I had to accept it, what else can I do if I am his wife? If I married him, I have to serve him, but that's not what I want (Discourse of the Collective Subject 1 - I1, I3, I5, I6, I8, I10, I12, I13, I15,I18).

\section{Summary central idea B: jealousy}

The discourse below presents how jealousy leads to conjugal conflicts, which end in triggering violence.

I am very jealous. Sometimes he is on the telephone and I notice that he is all excited and see that it's a woman. I couldn't stand it, I grabbed his cell phone and threw it on the street, on the ground, to break it [...] I was crazy, as if he were actually a possession, I think it's a bit unhealthy. He goes out a lot with friends and I feel a bit left out. He is very jealous too. It is very wearing. That behavior of telephoning the whole time, wanting to know where I am, who I am with, monitoring me, telling me what I have to do, and I go crazy with that. $H e^{\prime}$ s even jealous of people from my family. If I talk with my uncle, my cousin, straightaway he wanders over to see what's going on. And when he turns up and sees me doing something he doesn't like, he gets furious, he hits me, he punches me, slaps me, shouts, does everything
(Discourse of the Collective Subject 2 - I1, I2, I3, I5, I6, I7, I8, I11, I12 I14, I18).

\section{Summary central idea C: the partner's infidelity}

The discourse presented below illustrates how the partner's infidelity provokes conflicts between the spouses and, as a result, conjugal violence.

I knew he was out with women, but he denied it, and lied. He had had another woman for months. After this, he began to betray me openly: he picked up women, took them to the bar. He would go out and spend days away without telephoning, and then turn up as if nothing had happened. Well, I lost my patience, and a constant argument began, because I'm not the sort of person to keep my mouth shut, I don't stand for much, I said that I knew everything and that he was lying, being unfaithful to me. Our arguments are nearly always over women off the street who he picks up, and the last straw was when he got one of my friends pregnant. The other day I found out that he was with a woman, I went after him, but I didn't see her. When he came home, I went to sort it out, but he said that nothing like that had happened and that it was my fault, that I go listening to what other people say, and on top of that he hit me (Discourse of the Collective Subject 3 - I2, I3, I13, I15, I16, I18, I19).

\section{Summary central idea D: unplanned fatherhood and motherhood}

This discourse shows that unplanned motherhood and fatherhood leads to conflict between men and women, which triggers situations of violence.

Our relationship entered a crisis when our baby was born, because of my pregnancy, which was unplanned. He became, you know, aggressive. The first time that he hit me was when he found out that I was pregnant. And then... Everything transformed, everything changed. I think that his life became stormy. He would hit me every day, lots of swearing at me, abusing me, saying that the child was not his. He did a lot of bad stuff, he put a gun against my head, left me locked up at home, went out and then came back, and more punching. After we had children, it became worse, because before, he just wanted to have fun, and after, he saw that he would have to have responsibilities, and he didn't want to. So all of that agony began, the bad relationship, him complaining about everything, saying that I should've taken care of myself [the pregnancy], and lots of different thoughts about bringing up the child. All this made him hit me more. We don't have any time for leisure. There's no 
time for us to be alone together, because I have to care for the children, and I don't like leaving them with another person, and he says to leave them with neighbors, acquaintances, but the responsibility for them is mine. So I would stay at home with them [the children] and he would go out (Discourse of the Collective Subject 4 - I2, I4, I5, I7, I12, I14, I19).

\section{Summary central idea E: use of alcohol and drugs}

The discourse refers to living with a partner who uses alcohol and drugs, and makes clear that there is an association between the use of licit and illicit drugs, conjugal violence, and financial difficulties.

Actually, he drinks too much and uses a lot of drugs, cocaine, that is. It was like this: he would sleep on the street, and spend three days away from home. I didn't know he was a drug user when I got involved with him. The first time I found out that he used drugs was when he arrived home drugged to the gills and began hitting me for no reason, and we fought in the middle of the street, with everybody watching. He was working, and earning well, but it wasn't enough. He spends all the money he gets on drink and drugs. We began to have financial difficulties, there wasn't even money from medicine, once, when one of our children became ill. He has been arrested for selling drugs. This really upsets me, and causes us to argue too much, and as a result, life is just suffering. Everything has changed a lot since the beginning. Drugs change people (Discourse of the Collective Subject 5 - I1, I2, I3, I4, I5, I9, I13, I15, I16, I18).

\section{DISCUSSION}

The study showed that men and women's social construction is permeated by gender inequality, contributing to violence in the conjugal relationship. According to the women's discourse, the man thinks that he holds the knowledge and the power and that he is always right, thinks that he owns the woman, and that she owes him subservience and obedience, without being allowed to express her desires, wishes or points of view, and is never allowed to disagree with what her partner thinks.

The woman's social place is still perceived as restricted to the home, requiring attitudes of obedience and submission. This occurs because "society, through creating roles of submission and passivity for the woman, creates a space for male domination, in which the process of harming women is slow, gradual, and considered legal": ${ }^{17: 27}$ to the extent that until the middle of the $20^{\text {th }}$ century, crimes of passion did not make it to court and were even ac- cepted by society. Although feminism has struggled for women's equality and rights for decades, the differences of roles between the sexes are still alive and latent in society, causing a variety of consequences for those who experience this situation..$^{18-19}$

Furthermore, in relation to unequal social construction between the sexes, the study shows that the man feels that he is the woman's "owner", imposing control over how the same should behave, how she should dress, and her friendships. As a result, the woman loses her liberty and the right to come and go and to decide what is best for herself, withdrawing from the people who live around her. This context makes us reflect regarding what is termed psychological violence, defined by the Maria da Penha Law as conduct which causes emotional harm and reduction of self-esteem, which degrades the woman or controls her actions, making use of threats, shaming, and blackmail. ${ }^{9}$ These situations, permeated by jealousy, lead to strain on the couple's relationship and even to conjugal violence.

One study undertaken in Recife, in the State of Pernambuco, Brazil, showed that jealousy is among the main reasons indicated for losing emotional control and for frustrations in the relationship, and is of great importance in contributing to violence. Among the reasons which trigger conjugal violence, jealousy appears as the factor which generates the third most violence in a couple's life. On most occasions, this jealousy is caused by lack of trust and insecurity, which can lead to what are termed crimes of passion. ${ }^{20}$

Regarding jealousy on the part of the women, the discourse shows that these feel marginalized or rejected by the fact that the partner has other social relationships. As a result, it is perceptible that the women confuse power of control or possession (pathological jealousy) as being jealous: although both are similar, there are differences. Pathological jealousy is a serious affective disorder, which undermines and destroys the relationship and feelings; it is a disorder in which the protagonist-aggressor constantly feels threatened. ${ }^{21}$ It is relevant to note, moreover, that the manifestations of normal jealousy and pathological jealousy differ between the sexes. For women, the motivating factor is fear of emotional infidelity, while men are more distressed by the sexual infidelity of their partners. ${ }^{22}$

It is worth considering that, in the Brazilian culture, there are differing standards for morality and norms for (in)fidelity, as the men can be unfaithful, while the women cannot. Research indicates that the discovery of female infidelity 
intensifies violence against the woman by the partner. ${ }^{23}$ The present study's results corroborate a study undertaken on the dynamics of domestic violence with 30 couples living in the south of Brazil, which revealed that suspicion of female infidelity acts as one of the biggest triggers for arguments and episodes of violence. ${ }^{24}$

Unfortunately, the expressing of violent acts on the part of the spouses can even result in death. One study on crimes of passion, undertaken with those who had committed them and who were in prison, revealed that the motivation for homicide was betrayal on the part of the women. ${ }^{25}$ One study performed with HIV-positive men in Ribeirão Preto, São Paulo, Brazil, shows that women who have extraconjugal relationships are vulnerable to the experience of violence, and calls attention to the fact that this female infidelity may be imaginary. ${ }^{26}$ In this regard, the conjugal violence is manifested not only because of the woman's betrayal, but also because of suspicion of this, even when this is baseless.

Regarding extraconjugal relationships on the part of the men, the women's discourse reveals the practice of male infidelity. A study undertaken in Brasilia, in the Federal District, Brazil, observed a prevalence of extraconjugal relationships on the part of the partner, close to $48 \%$, this rate being similar to that of countries where polygamy is accepted. ${ }^{23}$

For many men, infidelity is seen as a right of the provider, involvement in extraconjugal relationships being natural. From this point of view, the fact of being a man often guarantees the right to infidelity, openly, and denying the woman's right to question this, the woman being expected to understand that infidelity is part of the male "instinct". ${ }^{26}$ However, in this study, the discourse reveals that the women do not accept their partners' extraconjugal relationships. In not accepting male infidelity, the woman transgresses the socially accepted roles, which constitutes a factor which precipitates/intensifies the violence in the conjugal relationship.

Another situation which intensifies the conjugal conflicts is children outside the marriage, the results of extramarital relationships. This concern stands out in the women's discourse, above all due to the parental relationship that the man may have with the child, and the eternal link which will be made with the child's mother, due to the emotional and financial support which a child requires. This event leads us to reflect on unplanned fatherhood/motherhood. It is worth emphasizing that pregnancy can also occur in couples in a stable relationship without being planned, a situation which also causes conflicts and, therefore, exposes the woman to the experience of conjugal violence.

Regardless of whether the pregnancy is planned or desired, studies show that the practice of violence by the spouses is common: Brazilian Ministry of Health data indicate that approximately $13 \%$ of women report an increase in the frequency and/or severity of violence in this period. Another study reveals that, during pregnancy, the prevalence of physical or sexual violence varies between $1 \%$ and $20 \% .{ }^{27} \mathrm{~A}$ study undertaken with 960 women attended in public health centers in Recife, Pernambuco, Brazil, demonstrated an increase in violence during pregnancy. ${ }^{28}$

Considering the expression and repercussions of violence on women's health, it is necessary for health professionals to be alert to recognize the problem. In the case of pregnant women, knowledge about the risk of complications is necessary, above all due to the experience of violence, such as: depression, low self-esteem, frequent vaginal bleeding, and the threat of premature labor, among others. ${ }^{29}$ As it is perceived that pregnancy makes the woman vulnerable to conjugal violence, a better understanding of this phenomenon is necessary.

There is a series of reasons for the occurrence of violence during pregnancy, such as: the pregnant woman's refusal to have sexual relations with the partner; aversion to the pregnant body, which can lead the man to lose interest in the woman, seeking extraconjugal relationships; the woman's neediness due to not feeling attention on the part of the partner; and the partner's lack of interest in the pregnancy and doubts about the child's paternity. ${ }^{30}$ Complementing these reasons, the women's discourse also revealed the fact of the partner not wanting children, and, as a result, not feeling himself to be responsible for the child.

Differences regarding child-rearing were also mentioned as conflictual situations, it being clear that questions of gender have a strong contribution: firstly, the man attributing the issue of contraception to the woman. From the male viewpoint, it is the woman's duty to protect herself from pregnancy, and afterwards, to care for the children. The social belief persists that it falls to the woman to care for the home, the husband and the children, this activity being considered by many to be intrinsic to the female role, as the woman is born and is prepared to be a woman-wife-mother. ${ }^{31}$ Situations where these roles are not accepted end in causing conflicts and, as a consequence, the experience of violence in the conjugal relationship. 
A quantitative study undertaken with couples in the non-metropolitan region of the Brazilian state of Rio Grande do Sul (RS) revealed that the couples have little time to be alone together, with the children triggering conjugal conflicts, as the couples lose intimacy and privacy. ${ }^{32}$ While the children can influence the conjugal relationship, causing conflicts, in a separate study they were indicated by the women as being a factor of reconciliation. ${ }^{19}$ Research ${ }^{4}$ also reveals there to be an association between having children and the woman's remaining in a relationship permeated by conjugal violence. One study revealed that many women with a history of conjugal violence stopped their process of separation and returned to live with the partner because they prioritized their children. ${ }^{32}$

It is important to emphasize that financial/ economic issues are one of the main problems triggering conjugal violence, ${ }^{33}$ with unemployment in itself not constituting a risk factor for conjugal violence. Thus, in the discourse, being compromised economically due to the use of licit and illicit drugs is noted. Instead of the partner using the money for something which would be for the family's common good, he spends it on his addiction, this consumption placing the family's financial situation at risk, this also being associated with the practice of crime to support the drug use. The consumption of alcoholic drinks by the partners is one of the main causes leading the partner to commit crime. ${ }^{20-34}$

Attention is also called to the fact that the women state that the use of drugs/alcohol is the event causing conjugal violence, it being considered that if this is absent, the conjugal relationship is healthier. The women studied declared that when their partners drink, they are transformed, attacking them, initially verbally, and then progressing to other types of violence. ${ }^{35-36}$ Women who report their partners for conjugal violence already understood this association, when they stated that their husbands hurt them when under the effect of alcohol. ${ }^{37-38}$ In this regard, suspending consumption of alcohol constitutes an element which promotes harmony in the couple's coexistence, as, in this period, aggressive acts are suspended. ${ }^{35}$

It is important to mention the implications of drug use for the couple's children. Studies on family violence depicted high rates of consumption of alcohol and drugs by the perpetrator, with the children generally witnessing violence between the couple and, sometimes, being the target of physical and sexual abuse. Thus, many of the conflicts between couples extend to the children. ${ }^{39-40}$ To this, moreover, in addition to the addiction, one can add the illegality of involvement in selling drugs, as reported in the discourse, increasing the risks and rates of morbidity and mortality from external causes. In addition, in recent years, selling drugs has been the main reason for women being imprisoned - often for being their partners' accomplices. ${ }^{41}$

Bearing in mind that violence is a social problem with serious repercussions for health, the strategies for confronting it must be guided towards the deconstruction of sexist values, culturally-nourished by gender inequalities. It is essential for there to be broad and articulated policies, supporting the guidelines defined by the National Policy to Confront Violence Against Women, so as to combat gender discrimination and ensure women's empowerment. ${ }^{42}$ It is necessary for there to be spaces for women, and men too, to reflect regarding the social construction of gender, which imprisons the former in the role of being dependent on and submissive to men, and ultimately naturalizes violence against women.

Women's empowerment to perceive the experience of violence is, without doubt, the first step towards deconstructing the idea which permeates society's imaginary of male power; it is an important strategy for preventing and confronting gender violence. Considering this study's findings, it is believed that women's empowerment represents a means of preventing conjugal conflicts, above all those embedded in the belief in male power, which naturalizes men's right to be unfaithful; which, in its turn, allows one to understand jealousy in conjugal relationships.

\section{FINAL CONSIDERATIONS}

The study revealed that the relationship of control and domination by the man of the woman, jealousy, the partner's infidelity, unplanned fatherhood and motherhood, and the use of alcohol and drugs are situations which cause conjugal conflicts, which end in precipitating and/or intensifying the violence in the relationship between the couple.

This understanding is essential for the process of confronting the phenomenon, as it offers support for thinking about actions for preventing such conflicts and, consequently, promoting the reduction of cases of conjugal violence and its implications for health, the economy, and society in general. In this regard, preparation on the part of the health team is considered extremely important, as this acts in a wide variety of spaces, due to the association of these situations with the experience of conjugal violence by the woman. 
The professionals who work in primary health care must be mentioned, considering that this is a space based upon the prevention of health problems and diseases, and the promotion of health. In this context, emphasis is placed on the nurses, as these are the principal managers of these centers and have the greatest link with the community and community health workers, being able to articulate the neighborhood associations, schools, Specialized Social Work Centers) Alcoholics Anonymous and the Psychosocial Care Centers, such that these precipitating and/or intensifying elements may be worked upon, seeking a respectful solution in combating the violence.

Emphasis is also placed on the importance of making spaces available so that the women - and their spouses - may have the opportunity to reflect on their relationships and find paths towards a respectful conjugal life, favoring a family relationship permeated by dialogue and, as a result, by the health of the entire family. These actions include the exercising of respectful means for the resolution of conflicts which appear in the couple's day-to-day life.

Although it has indicated situations which cause conjugal conflicts, this study is limited, as it does not present other strategies for their resolution, which do not use disrespectful or violent means. It is therefore suggested that studies should be undertaken identifying and analyzing strategies for the peaceful and respectful resolution of conflicts, and which encourage a culture of peace.

\section{REFERENCES}

1. Melman J, Ciliverti ME, Aoki M, Figueira Junior N. Tecendo redes de paz. Saúde Socied [online]. 2009 Mar [acesso 2011 Set 06]; 18(1):66-72. Disponível em: http:/ / www.scielo.br/scielo.php?script=sci_ arttext\&pid=S0104-12902009000500012.

2. Ministério da Justiça (BR). Secretaria Especial dos Direitos Humanos. Direitos Humanos e Mediação de conflitos. ITS Brasil: 2008 [acesso 2011 Mai 21]. Disponível em: http://www.unmp.org.br/index. php?option $=$ com_content\&view $=$ article\&id $=127: \mathrm{c}$ urso-qdireitos-humanos-e-mediacao-de-conflitosq \&catid=36: noticias\&Itemid $=61$

3. Watts N. Screening for domestic violence: a team approach for maternal/newborn nurses. AWHONN Lifelines. 2004 Dec; 8(3):210-9.

4. Miranda MPM, Paula CS, Bordin IA. Violência conjugal física contra a mulher na vida: prevalência e impacto imediato na saúde, trabalho e família. Rev Panam Salud Publica. 2010 Abr; 27 (4):300-8.

5. Thomazine AM, Oliveira BRG,Vieira CS. Atenção a crianças e adolescentes vítimas de violência intrafamiliar por enfermeiros em serviços de prontoatendimento. Rev Eletr Enf [online] $2009 \mathrm{Dez}$ [acesso 2012 Out 19]; 11(4):830-40. Disponível em: http:/ / www.fen.ufg.br/revista/v11/n4/v11n4a08.htm

6. França MRC, Moreno JL. Criativo pioneiro na história da terapia familiar. In: Vitale MAF, organizadora. Laços amorosos: terapia de casal e psicodrama. São Paulo (SP): Ágora; 2004. p.15-28.

7. Braz MP, Dessen MA, Silva NLP. Relações conjugais e parentais: uma comparação entre famílias de classes sociais baixa e média. Psicol Reflex Crit. 2005 Jul; 18(2):151-61.

8. Rosa AG, Boing AF, Büchele F, Oliveira WF, Coelho EBS. A violência conjugal contra a mulher a partir da ótica do homem autor da violência. Rev Saude Soc [online]. 2008 Set [acesso 2012 Set 18]; 17(3):152-60. Disponível em: http:/ / www.scielo.br/scielo.php?pid=S0104-12902008000300015\&script=sci_arttext

9. Brasil. Lei No 11.340, de 7 de agosto de 2006. Lei Maria da Penha. Diário Oficial da União, 08 de agosto de 2006. p. 1.

10. Brasil. Constituição Federal, 05 de outubro de 1988. Constituição da República Federativa do Brasil. Brasília, DF: Senado; 1988.

11. Pope C, Mays N. Pesquisa qualitativa na atenção à saúde. Porto Alegre (RS): Artmed; 2008.

12. Fundação de Amparo à Pesquisa do Estado da Bahia (FAPESB). Diretoria de inovação. Coordenação de tecnologias sociais e ambientais Enfrentamento da violência conjugal: estratégias para a garantia da segurança e saúde das famílias. Projeto financiado. Edital Segurança Pública. Pedido no 709/11.

13. Ministério da Saúde (BR), Conselho Nacional de Saúde, 10 de outubro de 1996. Resolução n. 196. Dispõe sobre pesquisa envolvendo seres humanos. Brasília (DF): CNS; 1996.

14. Minayo MCS. Introdução à metodologia das ciências sociais. O desafio do conhecimento: pesquisa qualitativa em saúde. $12^{\mathrm{a}}$ ed. São Paulo (SP): Hucitec; 2010.

15. Lefevre F, Lefevre AMC. O discurso do sujeito coletivo: um novo enfoque em pesquisa qualitativa (desdobramentos). $2^{\mathrm{a}}$ ed. Caxias do Sul (RS): Educs; 2005.

16. Lefevre F, Lefevre AMC, Marques MCC. Discurso do sujeito coletivo, complexidade e auto-organização. Ciênc Saúde Coletiva. 2009 Abr; 14(4):65-72.

17. Monteiro CFS, Souza IEO. Vivência da violência conjugal: fatos do cotidiano. Texto Contexto Enferm. 2007 Jan-Fev;16(1):26-31.

18. Santi LN, Nakano MAS, Lettiere A. A percepção de mulheres em situação de violência sobre o suporte e apoio recebido em seu contexto social. Texto Contexto Enferm [online]. 2010 [acesso 2013 Out 18]; 19(3):417-24. Disponível 
em: http:/ / www.scielo.br/scielo.php?script=sci arttext\&pid=S0104-07072010000300002

19. Cizino T, Ruth F, Almeida AM, Rozendo CA. Infidelidade masculina e violência doméstica: vivência de um grupo de mulheres. Cienc Enferm. 2008 Out; 14(2):39-46.

20. Melo ZM, Silva DM, Caldas MT. Violência intrafamiliar: crimes contra mulher na área metropolitana de Recife. Psicol Estudo. 2009 Mar; 14(1):111-9.

21. Seo KT, Bervique JÁ, Rondina RC. Principais fatores desencadeantes de ciúme patológico na dinâmica de relacionamento conjugal. Rev Cienc Psicologia. 2001 Mai; 3(5): 124-132.

22. Buss DM. A paixão perigosa: porque o ciúme é tão necessário quanto o amor e o sexo. Rio de Janeiro (RJ): Objetiva; 2000.

23. Moura LBA, Gandolfi L, Vasconcelos AMN, Pratesi R. Violências contra mulheres por parceiro íntimo em área urbana economicamente vulnerável. Rev Saúde Pública. 2009 Dez; 43(6):944-53.

24. Deeke LP, Boing AF, Oliveira WF, Coelho EBS. A dinâmica da violência doméstica: uma análise a partir dos discursos da mulher agredida e de seu parceiro. Saúde Soc. [online]. 2009 Jun [acesso 2013 Out 19];18(2):248-58. Disponível em: http:/ /www. scielo.br/scielo.php?script $=$ sci_arttext\&pid $=$ S0104$12902009000200008 \& \operatorname{lng}=$ en\&tlng=pt. 10.1590/ S0104-12902009000200008

25. Santiago RA, Coelho MTAD. O crime passional na perspectiva de infratores presos: um estudo qualitativo. Psicol Estud. 2010 Mar; 15(1):87-95.

26. Figueiredo MAC,Terenzi NM. Relações conjugais de parceiros HIV soropositivos concordantes: uma visão masculina. Psicol Estud. 2008 Dez; 13(4):8795. Disponível em:http://www.scielo.br/pdf/pe/ v15n1/a10v15n1.pdf

27. Ministério da Justiça (BR), Secretaria de Políticas para Mulheres. Balanço semestral do ligue 180 (janeiro à junho/2012). Brasília (DF): MJ; 2012 [acesso 2012 Dez 20]. Disponível em: http:/ / www. sepm.gov.br/publicacoes-teste/publicacoes/2012/ balanco-semestral-ligue-180-2012

28. Silva EP, Ludermir AB, Araújo TVB, Valongueiro SA. Frequência e padrão da violência por parceiro íntimo antes, durante e depois da gravidez. Rev Saúde Pública. 2011 Dez; 45(6):1044-53.

29. Moraes CL, Arana FDN, Reichenheim ME. Violência física entre parceiros íntimos na gestação como fator de risco para a má qualidade do pré-natal. Rev Saúde Pública 2010 Ago; 44(4): 667-76.
30. Santana SBF. Representação de casais sobre a violência doméstica na gravidez [dissertação]. Salvador (BA): Universidade Federal da Bahia, Programa de Pós-Graduação em Enfermagem; 2005.

31. Teykal CM, Rocha-Coutinho ML. O homem atual e a inserção da mulher no mercado de trabalho. Psico. 2007 Dez; 38(3):262-8.

32. Lima GQ, Werlang BSG. Mulheres que sofrem violência doméstica: contribuições da psicanálise. Psicol Estud. 2011 Dez; 16(4):511-20.

33. Mosmann C, Falcke D. Conflito conjugal: motivos e frequência. Rev SPAGESP. 2011; 12(2):5-16.

34. Rabello PM, Caldas Júnior AF. Violência contra mulher, coesão familiar e drogas. Rev Saúde Pública. 2007 Dez; 46(6):970-8.

35. Oliveira MM, Teixeira KMD, Santana MM, Oliveira PRC, Lélis CT, Freitas MCP, et al. Marcas Psicológicas da violência doméstica: análise de história de vida de mulheres de comunidades populares urbanas. Texto Contexto Enferm. 2009 Jan-Mar; 8(1):123-9.

36. Carvalho MFA, Menandro PRM. Expectativas manifestadas por esposas de alcoolistas no Centro Psicossocial Âlcool e Drogas. Rev Bras Promoç Saúde. 2012 Out-Dez; 25(4):492-500.

37. Lamoglia CVA, Minayo MCS. Violência conjugal, um problema social e de saúde pública: estudo em uma delegacia do interior do Estado do Rio de Janeiro. Ciênc Saúde Coletiva. 2009 Fev; 14(2):595604.

38. Vieira EM, Perdona GSC, Santos MA. Fatores associados a violência física por parceiro íntimo em usuárias de serviço de saúde. Rev Saúde Pública. 2011 Dez; 45(4):730-7.

39. Reichenheim ME, Dias AS, Moraes CL. Coocorrência de violência física conjugal e contra filhos em serviços de saúde. Rev Saúde Pública. 2006 Dez; 40(4):595-603.

40. Figlie N, Fontes A, Moraes E, Payá Roberta. Filhos de dependentes químicos com fatores de risco biopsicossociais: necessitam de um olhar especial? Rev Psiquiatr Clín. 2004 Jul; 31(2):53-62.

41. Souza KOJ. A pouca visibilidade da mulher brasileira no tráfico de drogas. Psicol Estud. 2009 Dez; 14(4):649-57.

42. Ministério da Saúde (BR), Secretaria Nacional de Enfretamento à Violência contra as Mulheres, Secretaria de Políticas para as Mulheres. Política nacional de enfrentamento à violência contra a mulher. Brasília (DF): Presidência da República; 2011. 